\title{
Innovations in Education-The Development of a New Pedagogical Technology of a Combinational Type, Focused on the Development of Personality of Students
}

\author{
Vera Zhurakovskaya ${ }^{1, *}$, Aleksandr Sichinava ${ }^{1}$, Tatyana Simakova ${ }^{1}$, Olga Olicheva ${ }^{2}$, \\ Sergey Rykov ${ }^{3}$, Julya Valeeva ${ }^{4}$, Anastasia Kulachinskaya ${ }^{5}{ }^{-}$and Svetlana Ilyashenko ${ }^{6}$ \\ 1 Department of Administration, Academy of Public Administration, 129344 Moscow, Russia; \\ avsichinava@yandex.ru (A.S.); ipktmvr@yandex.ru (T.S.) \\ 2 Istra City Lyceum, 143500 Moscow Oblast, Russia; licey-istra@mail.ru \\ 3 Department of Humanitarian Disciplines, The Military Academy of Strategic Rocket Troops n.a., \\ 143900 Balashikha, Russia; genderist@yandex.ru \\ 4 Department of Industrial Management, Kazan State Power Engineering University, 420066 Kazan, Russia; \\ valis2000@mail.ru \\ 5 Graduate School of Industrial Economics, Peter the Great St. Petersburg Polytechnic University, \\ 195251 St. Petersburg, Russia; a.kulachinskaya@yandex.ru \\ 6 Base Department of Trade Policy, Plekhanov Russian University of Economics, 117997 Moscow, Russia; \\ ilyashenko.sb@rea.ru \\ * Correspondence: gvera66@mail.ru
}

Received: 6 September 2020; Accepted: 14 October 2020; Published: 21 October 2020

\begin{abstract}
The paper considers the problem of adolescent and young students' personalities' development in the conditions of face-to-face and distance school learning. The scientific novelty of the study is the proposed classification of pedagogical technologies according to the degree of their novelty: modernized technology, combinational technology, progressive technology, pedagogical technology of the combinational type, the essence of which is shown in its title. A specific model of pedagogical technology of the combinational type "Teaching in cooperation, in a team using flipped classroom" was developed. The developed technology was implemented during the classes of the humanities and natural-mathematical cycles. Nine hundred and eight adolescent and young students (divided into experimental and control groups) and 32 teachers participated in the experimental work. To analyze the differences between the experimental and control groups in terms of the student's personality manifestation, several criteria and indicators were considered. For mathematical and statistical processing of the obtained results, the multifunctional statistical Fisher's F-test was used. Analysis of the implementation of the developed technology in the conditions of face-to-face and distance learning showed a positive dynamics of experience formation of the student's personality manifestation. This allowed the authors to consider the developed pedagogical means effective.
\end{abstract}

Keywords: combinational technology; flipped classroom; blended learning; e-learning; distance learning; student personality

\section{Introduction}

The e-learning and distance educational technologies are widely used in education programs of various levels and directions [1]. A growing interest in online education is recorded in all countries. Distance learning, digital transformation of education and growing competition in open distance education [2-8] together with open innovation issues [9-13] are the typical features of the modern world. 
E-learning is understood as the organization of educational process including information obtained from databases and used in the implementation of educational programs. The e-learning educational content can be taken from the Internet; the federal system of information educational resources developed within the framework of federal programs and projects; the textbook sets; or be developed by the teachers themselves [14-16]. The development of electronic educational resources and methodological materials for distance learning is an urgent task at the present stage.

E-learning opportunities can be implemented through the following modern resources: Rosetta Stone; Tell me More Ultimate; Livemocha, Bussuu, AlGeo [17-19]. The software product "1C: E-Learning" can be used for the development of online courses and electronic resources [20]. The Blackboard and Moodle software can also be used for the development of e-courses, their uploading and direct implementation of e-learning using distance learning technologies. The eFront, Moodle systems can be used for blended learning of students using e-learning tools [21]. The new trends in e-learning include the H5P service, which can be used to create and edit interactive videos, presentations, games, advertisements and so forth; Adapt Learning, a service for creating electronic content [22]; development of new interfaces for the exchange of mathematical ideas when teaching mathematics (the Case Study for MyMathLab Learning System, Lessons Learned from a Calculus E-Learning System), creation and implementation of new massive open online courses (MOOC) and Rich Media Platform for training mathematics teachers [23].

Distance learning technologies are defined as educational technologies, implemented mainly using information and telecommunication networks with indirect (at a distance) interaction between students and teachers [24]. The distance learning can be implemented in the following ways: synchronous (video conference lesson, webinar, chat, offline meetings), asynchronous (video lectures, e-mail, messengers) [25], through the integration of distance and face-to face components of electronic courses for blended learning of students. The latter uses the following algorithm: (1) student's independent work with the material; (2) fulfillment of test and training tasks; (3) the student's independent determination of the subsequent route of his work: determination of the reference material volume, training exercises and so forth; (4) performing tasks to check the learnt material; (5) discussion of results, answers to students' questions; (6) face-to-face classroom work [26]. Distance learning can be carried out through one of the types of blended learning: online electronic educational-methodical complex on the Moodle platform [27,28], DiSpace 2.0 platform, which allows one to manage seminars, consult, keep a journal, check the performed work, perform testing [29]. Flipped classroom is a new teaching methodology, which has received recognition in primary, secondary and higher educational institutions. The essence of it is that lectures are held outside the classroom, study time is devoted to solving problems, the teacher has a role of trainer and facilitator [30-32]

The course can include-(a) a content module-a section of educational materials, which contains web-links to the necessary resources on the topic under study, tests; (b) a help module in the form of a tooltip, a dialog box, a text file; (c) an interactive module-mail, small forum, chat, electronic conference, video conference and so forth; (d) an administrative module for managing the group [33]. For distance learning, researchers used the following tools and methods: paper books, online electronic educational publications, computer training systems in hypertext and multimedia versions, audio and video educational and information materials, laboratory remote workshops, simulators with remote access, information databases, electronic libraries with remote access and so forth [34]. Distance learning is implemented using the following resources: (a) lecture texts, methodological instructions for practical, laboratory exercises, control tasks and so forth, (MSWord, Excel, Adobe Reader, PDF-editor, etc.); (b) scanned printed texts; (c) text-graphic interactive and motivating educational materials (HTML hypertext markup language, programming languages JavaScript, PHP, Java, etc.); (d) interactive text-graphic multimedia materials ( $\mathrm{C}++$, Python, Java, etc.), in a form of Windows (Linux, Android) applications, including virtual laboratory and simulation environments, simulators and emulators of equipment and devices [35]. 
The UNESCO Institute for Lifelong Learning (UIL), the International Council for Open and Distance Education (ICDE) and StudyPortals (SP) have collaborated on a research project called "Impact of Distance Education on Adult Learning (IDEAL)." The IDEAL team published the final report of the research project "Closing the gap: opportunities for distance education to benefit adult learners in higher education", which gives a set of recommendations on program design and implementation, as well as national policies related to distance education [36].

World practice of distance learning at the present stage of education development includes the following methods, organizational forms, means:

- Teleconferences with trainees at remote sites using VideoConferencing technology [37];

- An innovative model of Virtual Business Projects (VBP) based on teamwork [38];

- Remote online lessons based on technologies of synchronous and asynchronous remote communication [39];

- Model of intelligent learning "Monitoring the environmental parameters in a Smart City", which, among other things, provides the creation of remote laboratories for students and so forth [40];

- Creation of breakthrough technologies using virtual reality (VR) environment, games and educational programs, leading to a creative result [41,42].

This result is provided by the transfer of education, which should become more modular, from the classroom to an informal setting and especially to the Internet [43]. Of great importance are also empirical research related to the achievement of student learning outcomes in non-traditional (virtual and distance) and traditional (practical) scientific laboratories, as well as studying the factors that must be taken into account when assessing the state and progress of research in this area [44-46].

Thus, the analysis of works on the problem of organizing the educational process from the standpoint of e-learning and distance learning technologies showed that it is necessary to develop the following ideas for organizing this process:

- Improvement of the flipped classroom methodology of the face-to-face and distance learning form, which still has not a uniform version;

- Integration of gaming and distance technologies that provide motivation for learning in online environment;

- Development of electronic educational resources for the implementation of distance learning;

- Improvement of psychological and pedagogical means that ensure self-regulation of students within the framework of distance learning, since it is based on the independent activities of students and so forth.

In our work we focus on the problem of adolescent and young students' personalities' development in the conditions of face-to-face and distance school learning. In this regard an interesting work is devoted to the study of relationship between flexible learning and self-regulating strategy of learners in the framework of distance learning. The results showed a positive impact of flexible learning and its three factors (time management, teacher contact and content) on self-regulatory learning strategies (cognitive, metacognitive and resource-based). Groups with high learning flexibility have shown that they use more learning strategies than groups with low flexibility $[47,48]$.

This work considers development of a new pedagogical technology of the combinational type, which is a system of technologies and teaching methods forming an indissoluble unity, integrity, united by a common concept, idea, algorithm. It integrates flipped classroom, game technology, a collective way of teaching technology, multilevel learning technology, rating assessment method. The developed combinational technology should contribute to the development of the student's personality, motivate students to learn in the online environment and promote their self-regulation. 


\section{Materials and Methods}

The study was carried out using theoretical methods (analysis, synthesis and generalization of data from theoretical sources, scientific publications, Internet resources, etc.), diagnostic methods (questionnaires, testing) and statistical methods for processing experimental data

The classification of innovative projects by M.M. Potashnik was considered, which includes:

- Retro-innovations, that is, innovations already known to some extent, described in the literature;

- Innovations of modification type having an analogue or prototype;

- Innovations of a combinatorial type, in which the known things are divided into parts and combinations of these parts result in something new, which gives a new educational effect;

- Radical innovations, which have no analogues, no prototypes, no preliminary prototypes [49].

Based on the classification of innovative projects by M.M. Potashnik, we propose to classify the pedagogical technologies according to the degree of novelty: modernized technology, combinational technology, progressive technology.

The pedagogical technology of the combinational type (PTCT) is not a mechanical sum of technologies and teaching methods aimed at achieving a certain result. It is a system of technologies and teaching methods forming an indissoluble unity, integrity, united by a common concept, idea, algorithm, the implementation of which focuses on the solution of the set goals.

We have developed and tested the technology of the combination type "Teaching in cooperation, in a team using flipped classroom", which contributes to the development of the personality of the student, their self-regulation, motivation of the learning of students in face-to-face and distance learning. This combinational technology includes the following technologies and methods: flipped classroom, game technology, a collective way of teaching (CWT) technology (V.K. Dyachenko), multilevel learning technology, rating assessment method. Further we present the detailed description of the developed PTCT, Figure 1.

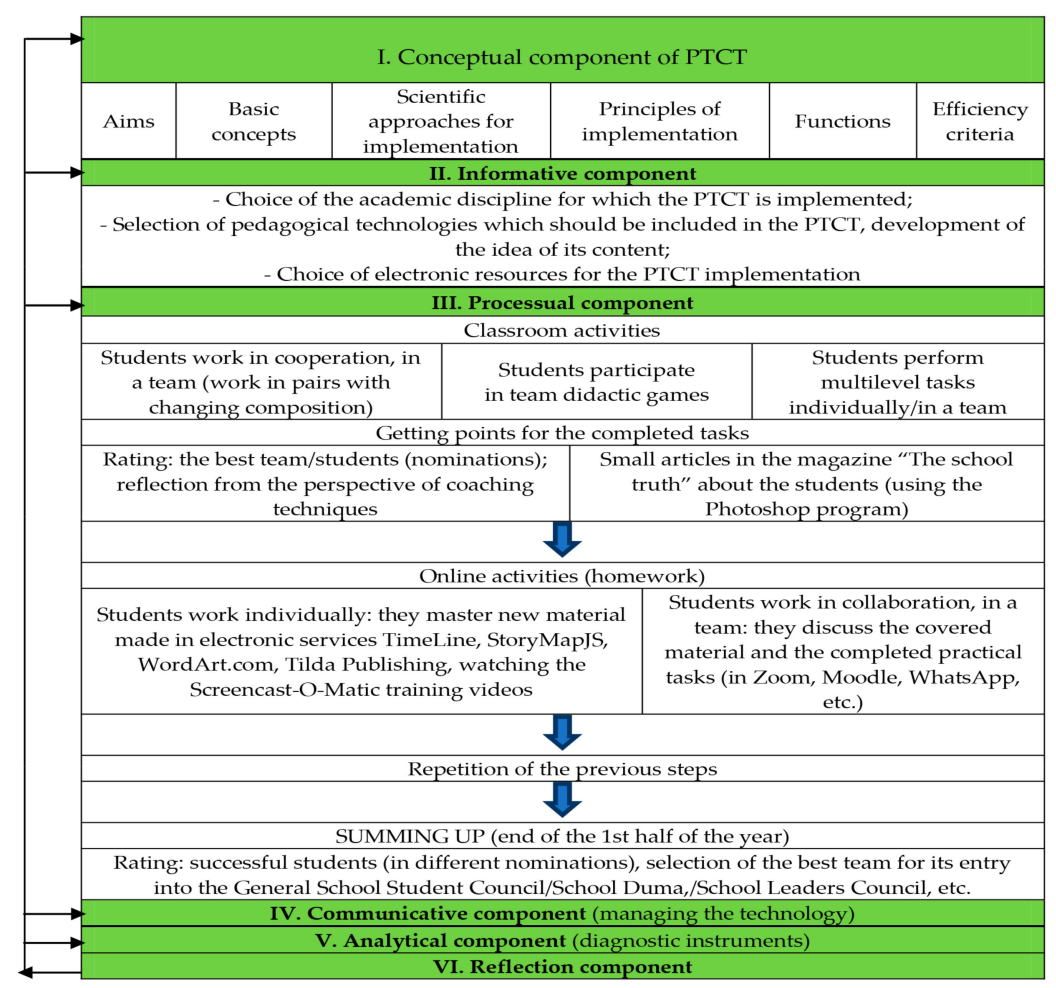

Figure 1. The model of the pedagogical technology of the combinational type (PTCT) "Teaching in cooperation, in a team using flipped classroom". 


\subsection{The Conceptual Component of Model}

It deals with the following issues:

(1) The purpose of the technology is to promote the development of the personality of students during the educational process of the school, expressed in the creation of conditions for the awareness and realization by students of the need to develop their personality.

(2) The theoretical and methodological basis of the combinational technology "Teaching in cooperation, in a team using flipped classroom" is the concept of developing the student's personality [50]. The main conceptual provisions include the following:

- The process of developing the personality of adolescent and young students passes the stages of self-knowledge, self-determination, self-creation, self-esteem, each of which consists of certain steps;

- The activity of teacher involves the creation of situations and conditions in which the student performs a free, conscious, alternative choice from 2/several opposite types of activity, involving the development of his personality, the formation of experience in decision-making;

- The transition of the external motivation of the student's activity into the internal one means that the teacher provides pedagogical support to the student in mastering the method of managing his activity motivation, which is expressed in the organization of goal-setting based on reflection from the position of communication with society, the key characteristics of personality, using coaching techniques, implementing techniques regulation by volitional actions, organization of a critical attitude towards oneself;

- The activity of teacher is to create conditions for effective processes of self-realization of students. It can be expressed in a breakthrough beyond the boundaries of the students' actual abilities (creativity), self-improvement, in their ability to positively surpass themselves. The task of teacher is to organize students to solve their problems, to perform creative tasks of heuristic, research, innovative, meaning-generating types, implying a breakthrough beyond the boundaries of the actual abilities of students (manifestation of their creativity), to develop the programs of self-education, self-development, the concept of "I am an personality", which determine the self-improvement of students [50].

(3) The scientific approaches to the technology implementation: personality-oriented, activity-based, coaching;

(4) The principles of the technology implementation: principles of pedagogical support, cooperation, freedom of choice, humanization, positive self-transcendence, subjectivity;

(5) The technology functions: self-improvement of students;

(6) The criteria for the effectiveness of technology: mentality, communication, self-development, morality, criticality.

\subsection{The Informative Component}

The combinational technology "Teaching in cooperation, in a team using flipped classroom" was implemented during the classes of the humanities and natural-mathematical cycles. The basic ideas for integrating the above listed technologies and methods into a single whole PTCT included:

- Creation motivation for the learning of students in the classroom, conditions for the development of personality of students, improving the quality of education, which was also ensured through the use of the "flipped classroom" methodology. According to it the teacher in the classroom forms students' skills and abilities to apply knowledge in practice and the development of new knowledge is carried out independently by students within the framework of online homework. In the classroom, the teacher uses CWT technologies, game technologies, multi-level teaching. Within the framework of these technologies, students complete tasks of different difficulty levels and receive points for 
this: 10 points for a low level of difficulty, 30 points for an average level of difficulty and 60 points for a high level of difficulty (rating methodology). As a result, the student, the team gets a rating (1st, 2nd, 3rd place, etc.), which provides status to students and his team in different nominations: best student of the year, best critic, analyst (of the quarters, semesters, year) or the most successful team, the most close-knit team and so forth. The best team of students can get the entry to the Duma of the school, the Council of Leaders and so forth. Achievements of students, teams are noted in the magazine "The school truth" (encouragement of students). Changing the student's status, his position, encouraging the student, according to the research of psychologists [51], ensures the inclusion of volitional processes, the regulation of volitional actions, that is, the development of his self-regulation, which is a mechanism for the student's self-development [52]. Self-development of a student is the basis for the development of his personality.

- Creation motivation for learning students online (homework), conditions for the development of personality of students, improving the quality of education:

(1) Through the use of electronic resources (TimeLine, StoryMapJS, WordArt.com, Tilda Publishing services), the Screencast-O-Matic program for the development of educational videos, on the basis of which content for homework was developed, providing students with enthusiasm and interest to independently master new knowledge;

(2) In order for the student to master the educational material, a discussion of new material is organized, the solution of problems in a team (in Zoom, Moodle, WhatsApp, etc.), since it is difficult for a teacher to conduct consultations every day for a large number of students. The team (of 6 people) has advanced students. To get the advanced students to want at a high level of responsibility, on the basis of a conscious, free choice to discuss, explain, advise team members (weak, average students), the algorithm was as follows. At the beginning of the classroom lesson, the teacher tested one student from the team (medium or weak, as a rule) on his homework mastering; and the points that the student received were received by the whole team. In addition, the teacher conducted reflection with the students from the perspective of coaching techniques, providing students with an understanding of why and how they need to carry out mutual assistance in a team while performing homework or class work. The received scores changed the status of the student, the team, which contributed to the development of self-regulation, which is the student's self-development mechanism. Self-development of students is the essence of the development of their personality.

The informative component of the model includes a description of electronic resources, based on which the homework related to mastering new knowledge was developed:

- TimeLine service is a free service for arranging content in chronological order; this service can contain text, educational video, links to Wikipedia and other text resources;

- StoryMapJS service is a free service for the uploading of the following content: text, instructional video, links to Wikipedia and so forth.

- WordArt.com service is a free service as a way of presenting text information: translation of words, interpretation of words and so forth, providing links to Wikipedia, explanatory, foreign dictionaries, Internet news publications and so forth.

- Tilda Publishing service is a free service that allows one to present educational information: educational videos, texts, content made in the services TimeLine, StoryMapJS, WordArt.com and so forth;

- Google classroom platform, which allows one to upload educational material, tasks for students, evaluate the work of students and so forth;

- Screencast-O-Matic program for recording training videos.

We offer the following methodology for using the content presented in the electronic services listed above: 
- Students identify important, key events in the text and their arrangement in chronological order in the TimeLine service;

- Students, whose biography is presented in TimeLine, determine, which process I shown in TimeLine and so forth.

- Students determine the missed dates and events contained in the TimeLine and fill in the missed content;

- Students find errors in the text (dates, sequence of events, etc.) presented in the TimeLine;

- Students answers to problematic questions to the text, located at the beginning/middle/end of the training video, electronic content;

- Students create a Booktrailer-a short video that reveals the essence of the viewed content, made in electronic services, programs;

- Students state problematic questions to the educational text, that can be put into their research, project work. A competition for the most difficult question is organized;

- Students/teacher develop a quest based on the content presented in electronic services, programs;

- Students develop a mind map based on the mastered electronic content in the MindManager/XMind/FreeMind program and so forth;

- Students/teacher develop problem cases based on the content of the viewed content, made on the basis of electronic services, programs;

- Students retell the mastered material offered in electronic resources, in the context of modern problems, moral problems, in the context of other academic disciplines and so forth;

- Students find in the text (from electronic resource) arguments, counterarguments, findings, conclusions, premises and designate them in different colors;

- Students develop a graphic image of the structure of argumentation of any thesis, a graphic image of the derivation of the thesis, taken from the text posted in any electronic service;

- Students develop a critical analysis of the text presented in any electronic resource.

\subsection{The Processual Component}

The stages of this component are presented in Figure 1.

\subsection{The Communicative Component (Managing the Technology)}

The technology implementation was managed through the activities of the project office. Teams of teachers implemented this technology at the parallels of the 6-7 grades using specially developed projects. The functions of the project office included the following:

- Coordination the plans of teachers' projects by time and resources among themselves;

- Receiving reports from project managers on the implementation of project activities;

- Reduction of resource conflicts at the level of the set of projects;

- Motivation of project managers to successfully implement projects by teachers.

The project office meets once a month under the leadership of the project set manager. They discuss the following themes: launching or suspension of project; building a monitoring system for the implementation of a set of projects; reporting for project managers; resolution of resource conflicts and so forth. The implementation of projects is monitored via regular analysis of reports. Monitoring can be carried out in the Trello service. The monitoring system includes the selection and assessment of various indicators of project implementation, expressed quantitatively and qualitatively.

The project manager directly manages the project implementation. He is responsible for the schedule, for managing the project activities of teachers. He receives reports from teachers on project implementation and provides them to the project office, motivates teachers to successfully implement their projects.

For the project implementation, the following tasks should be set and resolved by the project manager and teachers: 
- Setting the work directions of the teachers' team;

- Assigning persons in charge of the development of electronic content on the specified educational topics. Teachers should discuss the resulting electronic content as well as the experience of implementing this content, correct and improve it;

- Assigning persons in charge of the development of content of different disciplines from the position of knowledge integration based on different electronic services. Teachers should discuss the resulting content, correct and improve it discussion by teachers of the experience of implementing this content, its correction;

- Mutual training of teachers when working in various electronic resources (TimeLine, StoryMapJS, WordArt.com, Tilda Publishing, Google classroom, in the Screencast-O-Matic program); mastering new services;

- Identification of persons in charge of posting reports in the Trello service and so forth.

\subsection{The Analytical Component}

It includes the selection and compilation of diagnostic tools to determine the development of the student's personality. This is conditioned by the enrichment of experience of manifestation of his personality. By the experience of manifestation the personality of a student, we mean the ability in a peculiar, original way to show their unique properties and qualities in creating oneself, one's life path and reality. The components of the student's personality manifestation experience are the following: mental experience, communicative, spiritual and moral, self-development, critical thinking.

\subsection{The Feflection Component}

It includes comprehension, assessment, identification of shortcomings, forecasting ways of improvement and so forth.

\section{Results}

908 adolescent and young students and 32 teachers participated in the experimental work. The experimental group consisted of students from the Moscow and Kemerovo regions. The pedagogical experiment was carried out in the conditions of traditional educational process. The considered students groups are a continuous sample from a homogeneous environment of students of a general education school (the same curriculum, age (12-15 years), the same approximate general education program). The results obtained in the experimental group $(\mathrm{N} 1=116$ people) were compared with that from the control group (N2 = 119 people).

During the implementation of the PTCT "Teaching in cooperation, in a team using flipped classroom", the student's individual experience was monitored. The technology was implemented during the classes of the humanities (Russian language, foreign language, literature, history, etc.) and natural-mathematical cycles (mathematics, physics, chemistry, etc.). The indicators of the effectiveness of the formation of the experience of the manifestation of the student personality were the indicators of the formation of its structural components: mental experience, spiritual and moral, communicative, experience of critical thinking of students and self-development, Table 1.

The criteria for assessing the formation of the experience of student's personality manifestation include the following: mentality, communication, self-development, morality and criticality. Each of the structural components of the experience of student's personality manifestation was brought to four levels: high, above average, average and low. Based on the level characteristics of the structural components of the student's personality manifestation experience (mental, communicative, spiritual and moral experience, the experience of critical thinking and self-development), indicators of the formation of level characteristics of the student's personality manifestation experience were determined, expressed quantitatively and qualitatively. 
Table 1. Criteria and indicators for assessing the formation of experience in the manifestation of a student's personality.

\begin{tabular}{|c|c|c|}
\hline Assessment Criteria & Performance Indicators, Showing the Ability of Students To & Diagnostic Technique \\
\hline \multirow{4}{*}{ Mentality } & $\begin{array}{l}\text { Perform conceptual representation, which is the highest stage of intellectual } \\
\text { development; }\end{array}$ & \multirow{2}{*}{$\begin{array}{l}\text { A series of tasks for the formation of cognitive } \\
\text { experience, developed by the authors of the study }\end{array}$} \\
\hline & Construct a context between three concepts, which do not have a common meaning; & \\
\hline & Perform intellectual control; & \multirow{2}{*}{ Methods of metacognitive experience formation [53] } \\
\hline & Synthesize all kinds of cognitive positions. & \\
\hline \multirow{3}{*}{ Communicativeness } & Understand people, situations, communication partners; & \multirow{3}{*}{ KOSKOM 2 Questionnaire [54] (scales 1-2; 4; 12; 16) } \\
\hline & Enter into psychological contact, establish trusting relationships; & \\
\hline & Apply adequate skills in new communication situations. & \\
\hline \multirow{3}{*}{ Self-development } & $\begin{array}{l}\text { The formation of motives for self-determination, self-improvement, duty and } \\
\text { responsibility; }\end{array}$ & $\begin{array}{l}\text { Methodology for diagnosing educational motivation } \\
\text { of schoolchildren [55] }\end{array}$ \\
\hline & Follow the plan of self-development; & $\begin{array}{l}\text { Diagnostics of realization of needs for } \\
\text { self-development [56] }\end{array}$ \\
\hline & The ability to show citizenship, patriotism, etc. & $\begin{array}{l}\text { Diagnostics of the personal growth of a schoolchild } \\
\text { (scales } 2 ; 13) \text { [57] }\end{array}$ \\
\hline \multirow{3}{*}{ Morality } & Comprehend reality in moral assessments; & \multirow{3}{*}{$\begin{array}{l}\text { Methodology for diagnosing the real structure of } \\
\text { personal value orientations (scales } 1-6 ; 7-11 \text { ) [58]. } \\
\text { Diagnostics of the personal growth of a schoolchild } \\
\text { (scales 9; 10) [57] }\end{array}$} \\
\hline & Exercise moral self-determination; & \\
\hline & Relate to his spiritual self. & \\
\hline \multirow[b]{2}{*}{ Criticality } & Think clearly, concisely, correctly, etc.; & Logical thinking test [59] \\
\hline & Evaluate different points of view, etc. & $\begin{array}{l}\text { Methodology for diagnosing the level of reflexivity of } \\
\text { a student [60] }\end{array}$ \\
\hline \multicolumn{2}{|c|}{ Mentality, self-development, morality, criticality } & $\begin{array}{l}\text { e degree of formation of the experience of manifestation } \\
\text { onality, developed by the authors }\end{array}$ \\
\hline
\end{tabular}


The task of obtaining the necessary information about the effectiveness of the use of pedagogical resources in the educational process was solved. The following methods of pedagogical diagnostics were used: observation, questionnaire, testing, interviewing, self-assessment. The diagnostics was carried out by teachers working with students. The results were analyzed by the authors using the mathematical and statistical techniques. To analyze the differences between the experimental and control groups in terms of the level characteristics of the experience of the student's personality manifestation, a multifunctional statistical Fisher's F-test was used [61]. The distribution of students in the control and experimental groups was based on a random distribution (Fisher's randomization principle) while observing the "non-transparency" of such distribution into groups for all students. The alignment of objective conditions was carried out through the alignment of the composition of students (age, gender, level of formation of experience in the manifestation of personality of students, attitude in learning activities, interests, inclinations, ability to learn, content and volume of the studied, duration of activities carried out according to the same plan, one and the same approximate general educational program, etc.), a social environment, the priority values of which include creativity, self-realization, moral values. The alignment of the composition of the control and experimental groups was carried out on the basis of the conditional distribution of the participants into subgroups according to the levels of formation of the experience of the student's personality manifestation. The alignment of subjective factors was carried out through the implementation of the educational process in control and experimental classes by one or different teachers but approximately equal in terms of experience, skill, creative potential, personal qualities and so forth.

During the control stage of the experimental work we established indicators of the levels of formation of the experience of manifesting the student personality (Table 2).

Table 2. Assessment of indicators of level characteristics of the experience of manifestation of personality of students at the control stage in Istra, Protvino, Domodedovo, Lipitsy village.

\begin{tabular}{|c|c|c|c|c|c|c|c|}
\hline \multirow{2}{*}{ Groups } & \multicolumn{3}{|c|}{$\begin{array}{c}\text { "There Is an Effect": The Problem } \\
\text { Is Solved }\end{array}$} & \multicolumn{3}{|c|}{$\begin{array}{l}\text { "There Is No Effect": The Problem } \\
\text { Is Not Solved }\end{array}$} & \multirow[t]{2}{*}{ Total } \\
\hline & $\begin{array}{l}\text { The Amount of } \\
\text { Tested Students }\end{array}$ & $\%$ Share & & $\begin{array}{l}\text { The Amount of } \\
\text { Tested Students }\end{array}$ & $\%$ Share & & \\
\hline \multicolumn{8}{|c|}{ The First Level, High } \\
\hline 1st group, experimental & 30 & $(25.86 \%)$ & A & 86 & $(74.14 \%)$ & B & 116 \\
\hline 2nd group, control & 16 & $(13.44 \%)$ & $\mathrm{C}$ & 103 & $(86.56 \%)$ & $\mathrm{D}$ & 119 \\
\hline \multicolumn{8}{|c|}{ The Second Level, above Average } \\
\hline 1st group, experimental & 41 & $(35.34 \%)$ & $\mathrm{A}$ & 75 & $(64.66 \%)$ & B & 116 \\
\hline 2nd group, control & 25 & $(21 \%)$ & $\mathrm{C}$ & 94 & $(79 \%)$ & $\mathrm{D}$ & 119 \\
\hline \multicolumn{8}{|c|}{ The Third Level, Average } \\
\hline 1st group, experimental & 20 & $(17.24 \%)$ & A & 96 & $(82.76 \%)$ & $\mathrm{B}$ & 116 \\
\hline 2nd group, control & 35 & $(29.41 \%)$ & $\mathrm{C}$ & 84 & $(70.59 \%)$ & $\mathrm{D}$ & 119 \\
\hline \multicolumn{8}{|c|}{ The Fourth Level, Low } \\
\hline 1st group, experimental & 25 & $(21.55 \%)$ & A & 91 & $(78.45 \%)$ & B & 116 \\
\hline 2nd group, control & 43 & $(36.13 \%)$ & $\mathrm{C}$ & 76 & $(63.87 \%)$ & $\mathrm{D}$ & 119 \\
\hline
\end{tabular}

\section{Discussion: Open Innovation in Education and New Technology}

The experimental work confirmed the effectiveness of pedagogical resources and the conditions for their implementation, expressed in the dynamics of the experience of manifestation his personality. The students of the experimental groups showed the highest results of the formation of the experience of manifestation of personality of students at high $(25.8 \%)$ and above average levels (35.3\%), in contrast to students in the control groups ( $13.4 \%$ and $21 \%$, respectively). This was manifested in the ability of students to generate new, more effective ways to solve the problem, predict, revise traditional 
approaches and find new bases for decision-making (25\% of students in experimental groups, $12.6 \%$ in control groups); to present their opinion, coordinate it with partners, organize effective interaction with subjects of education (30.1\% of students in experimental groups, $16.8 \%$ in control groups); independently master new knowledge, methods of activity, take a social-ideological, civic position (23.2\% of students in experimental groups, $11.7 \%$ in control groups). The inability of students to reasonably, logically develop their own point of view, adequately assess information, problematize the situation is more pronounced among students in control groups $(31.9 \%$ of students in control groups and $18.1 \%$ in experimental groups). In the control group, $29.4 \%$ of students and in the experimental group, $16.3 \%$ of students did not have the ability to interpret reality in moral assessments. Students in the control (32\%) and experimental groups (18.1\%) showed a low level of skills to take an active life position, to be responsible for it. Table 3 presents the analysis of reliability of changes that occurred in students as part of the assessment of the formation of their personality manifestation.

Table 3. Assessment of significant differences in the formation of the experience of manifestation of personality of students between the control and experimental groups ( $\varphi_{\mathrm{emp}}$-empirical, $\varphi_{\text {crit }}$-critical).

\begin{tabular}{|c|c|c|c|c|}
\hline $\begin{array}{l}\text { Indicators of Level } \\
\text { Characteristics of the } \\
\text { Student's Personality } \\
\text { Manifestation Experience }\end{array}$ & $\varphi_{\mathrm{emp}} *$ & $\varphi_{\mathrm{emp}}{ }^{*}>\varphi_{\text {crit }}{ }^{*} ; \varphi_{\mathrm{emp}}{ }^{*}>2.31(p \leq 0.01)$ & N2 & N1 \\
\hline The first level, high & 2.42 & There are differences, $p \leq 0.01$ & 119 & 116 \\
\hline $\begin{array}{l}\text { The second level, above } \\
\text { average }\end{array}$ & 2.45 & There are differences, $p \leq 0.01$ & 119 & 116 \\
\hline The third level, average & 2.22 & $\begin{array}{l}\text { There are no differences, } \varphi_{\mathrm{emp}}{ }^{*}<\varphi_{\text {crit }} \text { area } \\
\text { of uncertainty }\end{array}$ & 119 & 116 \\
\hline The fourth level, low & 2.48 & There are differences, $p \leq 0.01$ & 119 & 116 \\
\hline
\end{tabular}

Analysis of the results of the formation of the experience of manifestation of personality of students in the control and experimental groups at the control stage of the experimental work carried out in the cities of the Moscow region (Istra, Protvino, Domodedovo, Lipitsy village) showed statistically significant differences between them. Higher rates were detected among students in the experimental groups. Higher rates were found among students in the experimental groups (Figure 2).

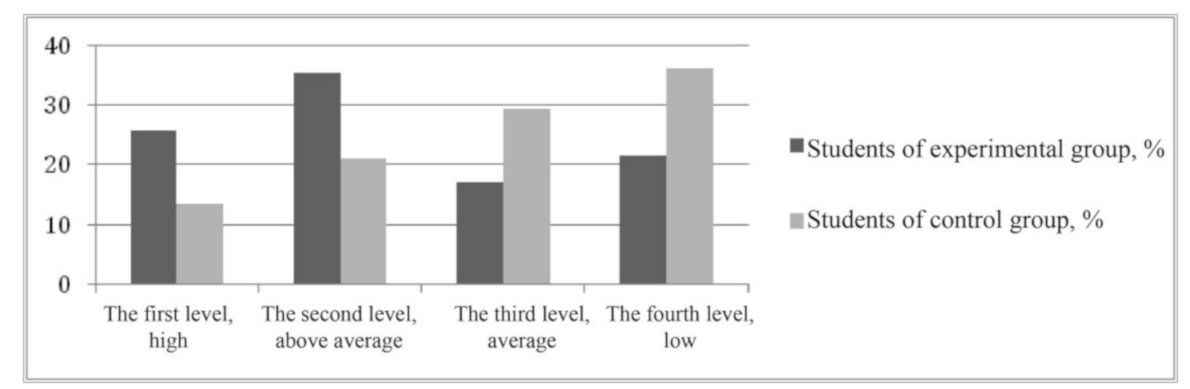

Figure 2. Indicators of the formation of the experience of manifestation of personality of students at the control stage in the city of Istra, Protvino, Domodedovo, p. Lipitsy (Moscow region).

The experimental work was carried out on the implementation of the system of psychological and pedagogical support for the development of the personality of the student in the educational process of the school. The developed innovative pedagogical technology of the combinational type can be considered as a new modern approach in education, making it consistent to the open innovation directions [62-65]. The analysis of the results showed a positive dynamics of the formation of the experience of manifestation of the personality of the student, which is an indicator of the level of development of his personality. 


\section{Conclusions}

The scientific novelty of the present study is the proposed classification of pedagogical technologies according to the degree of novelty: modernized technology, combinational technology, progressive technology, the pedagogical technology of the combinational type. The work presents the developed pedagogical technology of the combinational type "Teaching in cooperation, in a team using flipped classroom", implemented in the conditions of face-to-face and distance learning. The theoretical provisions being the basis of this technology are of high theoretical significance. The developed combinational technology is not a mechanical sum of technologies and teaching methods aimed at achieving a certain result. It is a system of technologies and teaching methods forming an indissoluble unity, integrity, united by a common concept, idea, algorithm, the implementation of which focuses on the solution of the set goals. The PTCT uses the content presented in the electronic services TimeLine, StoryMapJS, WordArt.com, Tilda Publishing, Google classroom, Screencast-O-Matic program, that shows its practical significance. The pedagogical conditions for the implementation of the described technology include a high level of innovative activity of teachers, which is a certain problem in education. Analysis of the implementation of the developed technology in the conditions of face-to-face and distance learning showed a positive dynamics of formation of the experience of the student's personality manifestation. Combinational-type pedagogical technology expands and enriches the theory of cognitive modeling of technologies for pedagogical support for the development of a student's personality and opens up new prospects for its intensive development. Further research can be focused on development of other combinational-type educational technologies based on new trends in e-learning and distance technologies.

Author Contributions: Conceptualization, V.Z. and A.S.; methodology, T.S.; O.O., A.K. and J.V.; formal analysis, S.R. and S.I.; investigation, A.S. and O.O.; literature review, S.R., J.V., S.I.; writing-original draft preparation, V.Z., A.S., O.O., T.S.; visualization, T.S., S.R., A.K.; project administration, V.Z. All authors have read and agreed to the published version of the manuscript.

Funding: This research work was supported by the Academic Excellence Project 5-100 proposed by Peter the Great St. Petersburg Polytechnic University.

Conflicts of Interest: The authors declare no conflict of interest.

\section{References}

1. Siemens, G. Massive Open Online Courses: Innovation in Education. In Open Educational Resources: Innovation, Research and Practice; Commonwealth of Learning, Athabasca University: Athabasca, AB, Canada, 2013.

2. Qayyum, A.; Zawacki-Richter, O. The State of Open and Distance Education. In Open and Distance Education in Asia, Africa and the Middle East; Springer: Singapore, 2019; pp. 125-140.

3. Segura-Robles, A.; Moreno-Guerrero, A.J.; Parra-González, M.E.; López-Belmonte, J. Review of research trends in learning and the internet in higher education. Soc. Sci. 2020, 9, 101. [CrossRef]

4. Pappas, M.A.; Demertzi, E.; Papagerasimou, Y.; Koukianakis, L.; Voukelatos, N.; Drigas, A. Cognitive-based E-learning design for older adults. Soc. Sci. 2019, 8, 6. [CrossRef]

5. Becker, B.A.; Eube, C. Open innovation concept: Integrating universities and business in digital age. J. Open Innov. Technol. Mark. Complex. 2018. [CrossRef]

6. Hariharasudan, A.; Kot, S. A scoping review on Digital English and Education 4.0 for Industry 4.0. Soc. Sci. 2018, 7, 227. [CrossRef]

7. Oke, A.; Fernandes, F.A.P. Innovations in teaching and learning: Exploring the perceptions of the education sector on the 4th industrial revolution (4IR). J. Open Innov. Technol. Mark. Complex. 2020, 6, 31. [CrossRef]

8. Firat, M. Understanding Turkish students' preferences for distance education depending on financial circumstances: A large-scale CHAID analysis. Int. Rev. Educ. 2017. [CrossRef]

9. Li, W.; Xu, J.; Zheng, M. Green governance: New perspective from open innovation. Sustainability 2018, 10, 3845. [CrossRef]

10. Yun, J.H.J.; Liu, Z. Micro- and macro-dynamics of open innovation with a Quadruple-Helix model. Sustainability 2019, 11, 3301. [CrossRef] 
11. Yun, J.H.J.; Zhao, X.; Jung, K.H.; Yigitcanlar, T. The culture for open innovation dynamics. Sustainability 2020, 12, 5076. [CrossRef]

12. Shin, K.; Kim, E.; Jeong, E.S. Structural relationship and influence between open innovation capacities and performances. Sustainability 2018, 10, 2787. [CrossRef]

13. Yun, J.J.; Zhao, X.; Park, K.B.; Shi, L. Sustainability condition of open innovation: Dynamic growth of alibaba from SME to large enterprise. Sustainability 2020, 12, 4379. [CrossRef]

14. Franzoni, A.L.; Assar, S. Student learning styles adaptation method based on teaching strategies and electronic media. Educ. Technol. Soc. 2009, 12, 15-29.

15. Gómez-Zermeño, M. Digital libraries: Electronic bibliographic resources on basic education. Comunicar 2012. [CrossRef]

16. Anisimova, T.I.; Krasnova, L.A. Interactive technologies in electronic educational resources. Int. Educ. Stud. 2015. [CrossRef]

17. Krasnova, E.V.; Panova, E.A.; Duseev, S.V.; Petrova, O.S. Methodological and technological capabilities of e-learning (on the example of teaching foreign languages). Train. Educ. Methods Pract. 2020, 1, 108-119.

18. Alekseeva, K.V. Teaching the Solution of Stereometric Problems Using Elements of e-learning and Distance Learning Technologies. Ph.D. Thesis, Herzen State Pedagogical University of Russia, Saint Petersburg, Russia, 2016.

19. Degtyareva, T.K. Improving the effectiveness of teaching students in the subject "Mathematics" through the use of the electronic learning tool "Algeo". In Proceedings of the Digital Transformation of Education: Electronic Collection of Abstracts of the 1st Scientific and Practical Conference, Minsk, Belarus, 30 May 2018; pp. 74-77.

20. Alibalaeva, L.I. The practice of using an electronic course based on "1C: e-learning" in face-to face education. In Proceedings of the New Information Technologies in Education: Collection of Scientific Papers of the 19th International Scientific and Practical Conference, Moscow, Russia, 29-30 January 2019; Chistova, D.V., Ed.; pp. 416-418.

21. Dmitriev, D.S. Formation of the Readiness of a University Teacher for the Use of e-Learning Tools in Professional Activity. Ph.D. Thesis, Samara National Research University, Samara, Russia, 2017.

22. Park, J.D. Recent e-learning trends. Her. Kyrg. State Univ. Constr. Transp. Archit. Named N. Isanov. 2014, 2, 58-65.

23. Nakamura, Y.; Yoshitomi, K.; Kawazoe, M. Distance Learning, e-Learning and Blended Learning in Mathematics Education; Springer: Berlin/Heidelberg, Germany, 2018; ISBN 978-3-319-90789-5.

24. Moore, J.L.; Dickson-Deane, C.; Galyen, K. e-Learning, online learning, and distance learning environments: Are they the same? Internet High. Educ. 2011. [CrossRef]

25. Ovchinnikova, A.V. Pedagogical Conditions for the Organization of Distance Learning of Students in a Rural School. Ph.D. Thesis, Yelets State University named after I.A. Bunina, Yelets, Russia, 2019.

26. Panikarova, N.F. Algorithm for the Integration of Distance and Face-to-Face Components in Electronic Blended Learning Courses. In Proceedings of the Information and Communication Technologies in Linguistics, Linguodidactics and Intercultural Communication: A Collection of Papers; Nazarenko, A.L., Ed.; Universitetskaya Kniga: Moscow, Russia, 2016; pp. 403-416.

27. Bekhterev, A.N.; Loginova, A.V. The distance learning system "MOODLE" in teaching a professional foreign language. Otkrytoe Obraz. 2013, 4, 91-97.

28. Kim, E.; Park, H.; Jang, J.U. Development of a class model for improving creative collaboration based on the online learning system (Moodle) in Korea. J. Open Innov. Technol. Mark. Complex. 2019, 5, 67. [CrossRef]

29. Legan, M.V.; Yatsevich, T.A. Combined model of teaching students based on the distance learning system. High. Educ. Russ. 2014, 4, 136-141.

30. Volkova, I.A. Project "School of Distance Learning" as a Distance Resource for Organizing Networking Blended learning, Proceedings of the Networking of Educational Organizations during Implementation of the Federal State Educational Standard: Modern Approaches, Experience and Prospects. Proceedings of the Regional Scientific and Practical Conference; Diagileva, N.V., Trofimova, O.A., Eds.; "Institute for Education Development” Sverdlovsk Regio: Ekaterinburg, Russia, 2016; pp. 40-48.

31. Altemueller, L.; Lindquist, C. Flipped classroom instruction for inclusive learning. Br. J. Spec. Educ. 2017, 44, 341-358. [CrossRef] 
32. Estrada, Á.C.M.; Vera, J.G.; Ruiz, G.R.; Arrebola, I.A. Flipped classroom to improve university student centered learning and academic performance. Soc. Sci. 2019, 8, 315. [CrossRef]

33. Aldiyarov, K.T.; Bidaibekov, E.Y. Model of teaching computer science, integrated with teaching general technical disciplines based on a combination of face-to-face and distance learning. Bull. Peoples' Friendsh. Univ. Russ. Ser. Informatiz. Educ. 2012, 3, 15-23.

34. Timofeeva, O.Y. Monitoring the quality of student teaching and professional competence of teachers through the distance learning system in the context of the Federal State Educational Standard. Munic. Obraz. Innovacii Exp. 2011, 4, 16-19.

35. Shatunovskiy, V.L.; Shatunovskaya, E.A. Once again about distance learning (organization and provision of distance learning). Bull. Sci. Educ. 2020, 9-1, 53-56.

36. Carlsen, A.; Holmberg, C.; Neghina, C.; Owusu-Boampong, A. Closing the Gap: Opportunities for Distance Education to Benefit Adult Learners in Higher Education; UNESCO Institute for Lifelong Learning: Hamburg, Germany, 2016; ISBN 978-92-820-1203-1.

37. Battat, R.; Jhonson, M.; Wiseblatt, L.; Renard, C.; Habib, L.; Normil, M.; Remillard, B.; Brewer, T.F.; Sacajiu, G. The Haiti Medical Education Project: Development and analysis of a competency based continuing medical education course in Haiti through distance learning. BMC Med. Educ. 2016, 16, 275. [CrossRef] [PubMed]

38. James, N.; Humez, A.; Laufenberg, P. Using Technology to Structure and Scaffold Real World Experiential Learning in Distance Education. TechTrends 2020, 64, 636-645. [CrossRef]

39. Lai, K.W. Pedagogical practices of NetNZ teachers for supporting online distance learners. Distance Educ. 2017, 38, 321-335. [CrossRef]

40. Nikolov, R.; Shoikova, E.; Krumova, M.; Kovatcheva, E.; Dimitrov, V.; Shikalanov, A. Learning in a Smart City Environment. J. Commun. Comput. 2016, 13, 338-350. [CrossRef]

41. Park, Y.H.; Paik, T.Y.; Koo, J.H. Effect of student activity participation on accounting education. J. Open Innov. Technol. Mark. Complex. 2019, 5, 40. [CrossRef]

42. Figueiredo, M.; Mafalda, R.; Kamensky, A. Virtual Reality as an Educational Tool for Elementary School. In Smart Innovation, Systems and Technologies; Springer: Berlin, Germany, 2019; Volume 198, pp. 261-267. [CrossRef]

43. Psotka, J. Educational games and virtual reality as disruptive technologies. Educ. Technol. Soc. 2013, 16, 69-80.

44. Brinson, J.R. A Further Characterization of Empirical Research Related to Learning Outcome Achievement in Remote and Virtual Science Labs. J. Sci. Educ. Technol. 2017, 26, 546-560. [CrossRef]

45. Byun, C.G.; Sung, C.S.; Park, J.Y.; Choi, D.S. A Study on the Effectiveness of Entrepreneurship Education Programs in Higher Education Institutions: A Case Study of Korean Graduate Programs. J. Open Innov. Technol. Mark. Complex. 2018, 4, 26. [CrossRef]

46. Asim, Z.; Sorooshian, S. Exploring the role of knowledge, innovation and technology management (KNIT) capabilities that influence research and development. J. Open Innov. Technol. Mark. Complex. 2019, 5, 21. [CrossRef]

47. Bergamin, P.B.; Werlen, E.; Siegenthaler, E.; Ziska, S. The Relationship between Flexible and Self-Regulated Learning in Open and Distance Universities. Int. Rev. Res. Open Distance Learn. 2012, 13, 101-123. [CrossRef]

48. Ah Kim, S.; Yun Ryoo, H.; Joo Ahn, H. Student customized creative education model based on open innovation. J. Open Innov. Technol. Mark. Complex. 2017, 3, 6. [CrossRef]

49. Potashnik, M.M. How to Prepare a Project for Grants: Teaching Aid; Pedagogical Society of Russia: Moscow, Russia, 2005.

50. Zhurakovskaya, V.M. Formation of the Personality of a Senior Pupil in the Educational Process: Monograph in 2 Parts: Part 1; Perspectiva: New York, NY, USA, 2014.

51. Ivannikov, V.A. Psychological Mechanisms of Volitional Regulation: Teaching Aid; Piter: Saint Petersburg, Russia, 2006.

52. Morosanova, V.I. Personal aspects of self-regulation of voluntary human activity. Psychol. J. 2002, $23,45$.

53. Kholodnaya, M.A. Cognitive Styles. On the Nature of the Individual Mind, 2nd ed.; Piter: Saint Petersburg, Russia, 2004.

54. Kunitsyna, V.N. KOSKOM 2 Questionnaire. Available online: http://azps.ru/tests/5/koskom.html (accessed on 19 October 2020). 
55. Badmaeva, N.T. The Influence of Motivational Factors on the Development of Mental Abilities: Monograph; Publishing House of VSSTU: Ulan-Ude, Russia, 2004.

56. Fetiskin, N.P.; Kozlov, V.V.; Manuilov, G.M. Socio-Psychological Diagnostics of the Development of Personality and Small Groups: Teaching Aid; Publishing House of the Institute of Psychotherapy: Moscow, Russia, 2002.

57. Stepanov, P.V.; Grigoriev, D.V.; Kuleshova, I.V. Diagnostics and Monitoring of the Upbringing Process in School; Selivanova, L.N., Lizinsky, V.M., Eds.; APK and PRO: Moscow, Russia, 2005.

58. Bubnova, S.S. Methods of diagnostics of the individual structure of personal value orientations. Methods Psychol. Diagn. 1994, 2, 56.

59. Veselovskaya, E.V. Pedagogical Diagnostics of Logical Thinking of Students. Ph.D. Thesis, Vologda State Pedagogical University, Vologda, Russia, 2002.

60. Ilyina, E.V. Reflexive Management of Teaching of Students of a Comprehensive School. Ph.D. Thesis, Barnaul State Pedagogical University, Barnaul, Russia, 1998.

61. Sidorenko, E. Methods of Mathematical Processing in Psychology; OOO “Rech": Saint Petersburg, Russia, 2000.

62. Yun, J.J.; Lee, M.H.; Park, K.B.; Zhao, X. Open innovation and serial entrepreneurs. Sustainability 2019, 11, 5055. [CrossRef]

63. Roša, A.; Lace, N. The open innovation model of coaching interaction in organisations for sustainable performance within the life cycle. Sustainability 2018, 10, 3516. [CrossRef]

64. Yun, J.H.J.; Won, D.K.; Park, K.B. Entrepreneurial cyclical dynamics of open innovation. J. Evol. Econ. 2018, 28, 1151-1174. [CrossRef]

65. Yun, J.J.; Kim, D.; Yan, M.R. Open innovation engineering-Preliminary study on new entrance of technology to market. Electronics 2020, 9, 791. [CrossRef]

Publisher's Note: MDPI stays neutral with regard to jurisdictional claims in published maps and institutional affiliations. 